\title{
Koroner bypass operasyonlarında safen ven grefti hazırlama tekniklerinin karşılaştırılması
}

\section{Comparison of saphenous vein graft harvesting techniques for coronary artery bypass graft surgery}

\author{
Onur ŞEN*, Ersin KADIROĞULLARI
}

İstanbul Mehmet Akif Ersoy Göğüs Kalp Damar Cerrahisi Eğitim ve Araştırma Hastanesi

\section{öz}

Amaç: Bu çalışmada koroner bypass cerrahisi (CABG) sırasında safen ven grefti hazırlanırken tek ya da iki bacaktan safen ven grefti çıkartmanın bacak ağrısı, sellülit ve ödem açılarından aralarında fark olup olmadığı araştırıldı.

Gereç ve Yöntemler: CABG yapılacak ardışık 80 hasta çalışmaya alındı. Kırkar hastadan oluşan iki grup oluşturuldu. Gurup-1 de safen ven grefti tek bir bacaktan ve diz eklemini geçecek bir insizyonla hazırlandı. Gurup-2 de ise safen ven grefti hazırlanırken her iki bacaktan birer tane greft alınacak şekilde, diz eklemini geçmeyen insizyonlar yapıldı. Olguların insizyon yapılan bacak çevreleri, preoperatif evrede, postoperatif 1. hafta ve 1. aylarda, insizyonun 15 . cm'den ölçüldü. Hastalar postoperatif üçüncü günde, mobilize olduklarında, bacak ağrısı sorgulandı.

Bulgular: Her iki grupta da bacak çevresi ölçüm değerleri ve sellülit tablosu görülmesi benzer bulundu ve istatistiksel fark saptanmadı ( $p>0.05$ ). Ancak bacak ağrısı yönünden birinci gruptaki hastaların şikayetlerinin diğer gruba göre daha fazla olduğu saptandı $(p<0.05)$.

Sonuç: Koroner bypass operasyonu için safen ven grefti hazırlanırken cerrahi insizyon seviyesinin diz eklem seviyesi üzerine çıkmaması, hastaların olası bacak ağrısı şikayetinin daha az olmasını sağlayacaktır.

Anahtar Kelimeler: safen ven greft, koroner arter bypass greft, bacak ağrısı, sellülit

Sorumlu Yazar*: Onur ŞEN, İstanbul Mehmet Akif Ersoy Eğitim Araştırma Hastanesi, Kalp Damar Cerrahisi Kliniği, Istanbul/Türkiye 


\section{ABSTRACT}

Aim: The study aimed to compare bilateral versus unilateral saphenous vein graft harvesting during coronary artery bypass grafting (CABG) in terms of leg pain, edema, and cellulitis.

Material and Methods: Consecutive 80 patients that would undergo CABG surgery were equally randomized to unilateral and bilateral harvesting groups. While saphenous vein graft was harvested from one extremity where the incision was extended beyond the knee level, it was harvested from both extremities where incisions did not exceed the knee level. Diameter of legs incised were measured from $15 \mathrm{~cm}$ of the incision preoperatively, and at both postoperative week 1 and month 1. Subjects were asked for rating their leg pain intensity on postoperative day 3 after being mobilized.

Results: Both groups showed statistically comparable values in terms of mean diameter of leg and rates of cellulitis. Pain score in the first group was found as significantly higher compared with that of the second group $(p<0.05)$.

Conclusion: In saphenous vein graft harvesting for coronary bypass graft surgery, preference of an incision that do not exceed the knee level would provide less complaints of leg pain.

Keywords: saphenous vein graft, coronary artery bypass graft, leg pain, cellulitis

\section{Giriş}

Günümüzde koroner bypass cerrahisinde (CABG) LiMA (left internal mammary artery) ve radiyal arter gibi arteriyel greft kullanımı tercih edilse de safen ven; gerek kolay ulaşılması, gerekse de kolay hazırlanması açısından vazgeçilmez bir grefttir. Genellikle safen ven grefti (SVG) iç malleol anterioründen başlayan kesi ile hazırlanır. Bu yöntemle SVG hazırlanan olgularda postoperatif evrede sellülit ya da geç evre bacak ödemi gibi komplikasyonlar gelişebilir [1]. Klasik kesi ile SVG hazırlanan olgularda bacak komplikasyon oranı \%2-4 arasında değişmektedir [2]. Son yıllarda bu komplikasyonları azaltmak için endoskopik yöntemler veya modifiye insizyonlar tanımlanmıştır $[3,4,5]$.

Bu çalışmada amacımız, birden fazla safen ven grefti ihtiyacı olan CABG operasyonlarında; yalnızca bir bacaktan, diz eklemini geçen insizyon yapılarak SFG hazırlanan hastalar ile diz eklemini geçmeden yapılan insizyonlarla her iki bacaktan SFG hazırlanan hastalar arasında sellülit, ödem ve bacak ağrısı açısından fark olup olmadığını tespit etmektir.

\section{Gereç ve Yöntemler}

Hastanemiz etik kurulunun onayı alındıktan sonra, Ocak 2017- Nisan 2017 tarihleri arasında elektif CABG operasyonu uygulayacağımız ve safen ven grefti kullanılacak 46 'sı erkek, 34'ü kadın ardışık 80 hasta, randomize olarak 40'ar hastadan oluşan 2 gruba ayrıldı. Çalışmaya alınan hastalar bilgilendirildi ve onayları alındı. Birinci gruptaki olguların yaş ortalaması $61.0 \pm 6.0$ (minimum 56 maksimum 78 ) olup, ikinci gruptaki hastaların yaş ortalaması $60.3 \pm 6.6$ (minimum 51 maksimum 77 ) idi. Grup 1, 22'si erkek, 18'i kadın toplam 40 olgudan, Grup 2 ise 24 'ü erkek, 16'sı kadın 40 olgudan oluşmaktaydı.
Safen venler aynı cerrah tarafından hazırlandı. Daha önceden geçirilmiş kardiak cerrahi, venöz tromboz öyküsü, venöz yetmezlik, safeno-femoral yetmezlik öyküsü bulunan, vücut kitle endeksi $>30 \mathrm{~kg} / \mathrm{m}^{2}$ olan, diyabetik olan hastalar ile acil operasyonlar çalışma dışı bırakııdı.

Bizim çalışmamızda her iki gruba ait serum kreatinin, BUN ve albumin düzeyi ile SVEF değerleri fizyolojik sınırlardaydı ve aralarında istatistiksel anlamlı fark yoktu (Tablo 1).

\begin{tabular}{|c|c|c|c|}
\hline & $\begin{array}{l}\text { Grup } 1 \\
(n=40)\end{array}$ & $\begin{array}{l}\text { Grup 2 } \\
(n=40)\end{array}$ & $\mathbf{p}$ \\
\hline Yaş (yıl) ( $\pm S D$ ) & $61.0 \pm 6.0$ & $60.3 \pm 6.6$ & 0.62 \\
\hline LVEF (\%) ( \pm SD) & $57.9 \pm 5.9$ & $59.3 \pm 5.6$ & 0.62 \\
\hline Toplam greft sayısı n & 3.4 & 3.7 & 0.31 \\
\hline KPB süresi (dak) ( \pm SD) & $80.1 \pm 7.0$ & $79.5 \pm 6.9$ & 0.85 \\
\hline Klemp süresi (dak) ( \pm SD) & $46.6 \pm 4.9$ & $46.4 \pm 4.8$ & 0.96 \\
\hline BUN (mg/dL) ( $\pm S D)$ & $20.9 \pm 3.3$ & $20.6 \pm 3.4$ & 0.97 \\
\hline Kreatinin (mg/dL) ( $\pm \mathrm{SD})$ & $0.91 \pm 0.2$ & $0.90 \pm 0.2$ & 0.93 \\
\hline Total Protein $(\mathrm{g} / \mathrm{dL})( \pm \mathrm{SD})$ & $7.6 \pm 3.9$ & $7.8 \pm 4.2$ & 0.61 \\
\hline Albumin $(\mathrm{g} / \mathrm{dL})( \pm \mathrm{SD})$ & $4.4 \pm 0.2$ & $4.3 \pm 0.3$ & 0.96 \\
\hline
\end{tabular}

\section{Safen Ven Greft Hazırlama Tekniği}

Grup 1'de safen ven grefti cerrahi asistan doktor tarafından, tek bacaktan, iç malleolün hemen üstünden başlayan ve diz eklemini geçecek şekilde yapılan kesi ile hazırlandı (Resim 1A). Hem greft, hem de hasta tarafındaki venöz yan dallar 4/0 ipek sütür ile bağlandı. Disseksiyon seyri boyunca ligasyon ile kanama kontrolü yapıldı. Koter kullanılmadı. Greft hazırlandıktan sonra cilt altı doku ve cilt absorbabl sütür ile kapatıldı. Steril bandajlarla intraoperatif evrede bacak distalden proksimale doğru sarıldı. 
Grup 2'de ise safen ven greftleri, aynı asistan tarafindan, yine iç malleolün hemen üstünden başlayan yaklaşık $25 \mathrm{~cm}$ uzunluğunda olan ve diz eklemine ulaşmayacak şekilde, her iki bacak kesileri ile hazırlandı (Resim 1B). Hem greft hemde hasta tarafındaki venöz yan dallar, ilk gruptaki gibi, 4/0 ipek sütür ile bağlandı. Kanama kontrolü diseksiyon seyri boyunca ligasyon ile yapıldı. Cilt altı doku ve cilt absorbabl sütür ile kapatıldı. Ardından steril bandajlarla intraoperatif evrede bacak hemen sarıldı.

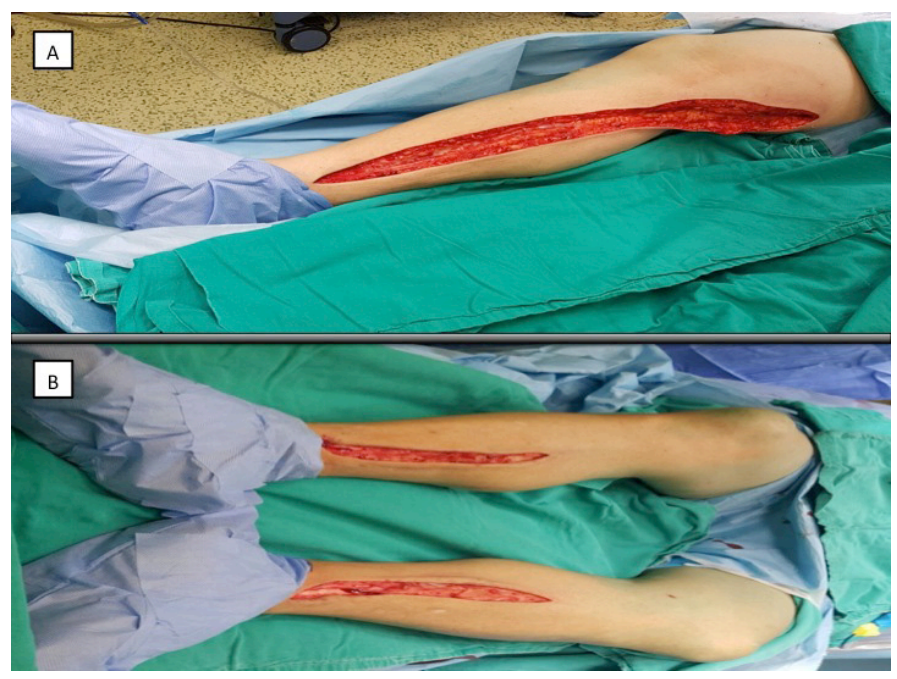

Resim 1: (A) Aynı bacak kesisi ile safen ven greft hazırlanması. (B) Diz eklemini geçmeyen insizyon ile her iki bacaktan safen ven greft hazırlanması.

Birinci gruptaki olguların insizyon yapılan bacak çevreleri, preoperatif evrede, postoperatif 1 . hafta ve 1. aylarda, insizyonun 15. cm'den ölçüldü.

İkinci gruptaki olguların ise her iki bacak çevreleri, preoperatif evrede, postoperatif 1 . hafta ve 1. aylarda, insizyonun 15 . cm'den ölçüldü. Çıkan ölçüm toplanıp ikiye bölünerek ortalaması alındı.

Her iki gruptaki hastalara düşük basınçlı ve diz üstü varis çorabı tedavisi bir ay süreyle uygulandı.

Hastaların ağrı dereceleri, hissedilen ağrı şiddetinin nispeten en düşük olduğu, postoperatif 3 . günde rakamsal skala (Numerical Rating Scale) yöntemi ile tespit edildi [6]. Hastalar, 0'ın ağrısızlığı,10'un olabilecek en şiddetli ağrıyı belirttiği 0-10 arasındaki bir skalada ne şiddette bacak ağrısı duyduklarını ifade ettiği bu yöntemle, ağrı açısından karşılaştıııldı.

\section{İstatistiksel Analiz}

Kullanılacak istatistik yöntemi ise değişkenlerin dağılımının bilgisayar ortamında sınıflandırılması ve IBM Statistical Package for the Social Sciences versiyon 20 (SPSS Inc., Chicago, IL, USA) programı kullanılarak istatistiksel sonuçların elde edilmesi

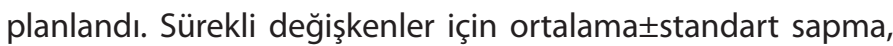

kategorik değişkenler için yüzde ve sayı değerleri verildi. Grupların normal dağılıma uygun olup olmadığı Kolmogorov Smirnov testi ile değerlendirildi ve dağılım sonucuna göre ortalamaların karşılaştııılması için MannWhitney UveyaStudent T testi uygulandı. Kategorik değişkenlerin karşılaştııılması için Ki-kare ve Fisher's exact testleri kullanıldı. Sonuçlarda $p<0.05$ değeri istatistiksel olarak anlamlı kabul edildi.

\section{Bulgular}

Her iki grubun alt ekstremiteye ait ölçülen bacak çapları Tablo 2'de verilmiştir. Preoperatif dönemde yapılan ekstremite bacak çap ölçümlerinde grup 1 ve grup 2 arasında istatistiksel olarak anlamlı fark olmadığı gibi, postoperatif 1. hafta ve 1. ayda yapılan bacak çap ölçümlerinde gruplar arasında istatistiksel anlamlı fark yoktu ( $p>0.05)$.

\begin{tabular}{|c|c|c|c|}
\hline & $\begin{array}{l}\text { Grup } 1 \\
(n=40)\end{array}$ & $\begin{array}{l}\text { Grup } 2 \\
(n=40)\end{array}$ & p \\
\hline Preoperatif bacak çapı (cm) $( \pm$ SD) & $35.1 \pm 1.2$ & $34.8 \pm 1.3$ & 0.88 \\
\hline Postoperatif 1.hft bacakçapı (cm) ( \pm SD) & $38.5 \pm 2.0$ & $37.8 \pm 1.8$ & 0.54 \\
\hline Postoperatif 1. ay bacak çapı (cm) ( \pm SD) & $35.9 \pm 1.3$ & $35.7 \pm 1.2$ & 0.87 \\
\hline Toplam kesi uzunluğu (cm) ( \pm SD) & $50.3 \pm 3.4$ & $54.7 \pm 3.1$ & 0.94 \\
\hline Sellülit n (\%) & $3(\% 7.5)$ & $2(\% 5)$ & 0.64 \\
\hline SD, standard deviation & & & \\
\hline
\end{tabular}

Sellülit yönünden grup 1'de 3 hasta (\% 7.5), grup 2'de 2 hasta (\% 5) olduğu görüldü ( $p=0.64)$.

Hastaların ameliyat sonrası 3. gündeki bacak ağrısı Numerical Rating Scale yöntemine göre değerlendirmesi Tablo 3'de gösterilmiştir. Ağrı seviyesini 1 olarak değerlendiren hasta sayısı grup 1 de 6, grup 2 de 10; 2 olarak değerlendiren hasta sayısı grup 1 de 6, grup 2 de 10; 6 olarak değerlendiren hasta sayısı grup 1 de 10, grup 2 de 1; 7 olarak değerlendiren hasta sayısı grup 1 de 6, grup 2 de 0 olarak bulundu. Diğer değerlerde ise sayılar yaklaşık olarak benzer idi. Bu bulgulara göre grup 1'de ağrı şikayeti istatistiksel anlamlı olarak fazla bulundu $(p=0.006)$.

\begin{tabular}{|c|c|c|}
\hline & Grup $1(n=40)$ & Grup $2(n=40)$ \\
\hline 1 şiddeti & 6 & 10 \\
\hline 2şiddeti & 6 & 10 \\
\hline 3 şiddeti & 4 & 7 \\
\hline 4 şiddeti & 1 & 5 \\
\hline 5 şiddeti & 6 & 7 \\
\hline 6 şiddeti & 10 & 1 \\
\hline 7 şiddeti & 6 & 0 \\
\hline 8 şiddeti & 1 & 0 \\
\hline
\end{tabular}

\section{Tartışma}

Klasik CABG operasyonları sırasında SVG hazırlanırken kesi, iyi bir anatomik belirleyici olan iç malleolün anteriorunden başlar ve venöz greft ihtiyacına göre yukarıya uzatıır. Bu işlem 
sırasında olguların yaklaşık olarak \%5'inde ven çıkarılan bacakta enfeksiyon gelişmektedir [7]. Bu oran kadınlarda, özellikle diabetes mellitus, periferik vasküler hastalık, bozulmuş sol ventrikül fonksiyonları olan olgularda daha da yüksektir [8].

Safen ven greft hazırlanmasına bağlı gelişen bacak komplikasyonlarını azaltmak için çeşitli yöntemler geliştirilmeye çalışılmıştır. Bunlar Mayo ven stripper modifikasyonu, safen ven trasesinde aralıklı insizyonlar yapılması ve özellikle son yıllarda giderek yaygınlaşan endoskopik tekniklerle ven hazırlanması yöntemleridir $[5,9,10]$. Terada ve arkadaşları yaptıkları çalışmada normal venöz dolaşıma sahip kişilerde SVG hazırlanmasının alt ekstremitede venöz fonksiyon bozukluğu ve ödem gelişimine sebep olmadığını göstermişlerdir [11]. Pagni ve arkadaşları ise yaptıkları çalışmada video-assist safen ven greft hazırlanması ile postoperatif ağrının, klasik yöntemle safen ven hazırlanan vakalara göre daha az olduğunu, fakat ödem gelişimi yönünden gruplar arasında fark olmadığını tespit etmişlerdir [12]. Biz yaptığımız araştırmada bu çalışmalarda fazla değinilmemiş, insizyon ve dolayısıyla kullanılan safen ven boyunun ödem ve sellülit gelişimine etkisini saptamayı amaçladık. Yine diz eklemini geçen insizyonu olan hastalar ile her iki bacakta fakat daha kısa insizyonu olan hastaları bacak ağrısı açısından karşılaştırdık.

Klasik kesi ile SVG hazırlanmasını takiben bacak ödemi sık gelişir, ancak bu ödem nadiren kalıcıdır. Ödem safen ven kullanımı dışında, renal yetmezlik, hipoalbuminemi ve kalp yetmezliği gibi sistemik nedenlerle de gelişebilir. Ancak bu tablolarda hastaların kan üre azotu (BUN), kreatinin, albümin değerleri ve sol ventrikül ejeksiyon fraksiyonu (SVEF) normal değildir.

Bacak ödemini tespit etmenin en doğru yolu bacak volümü ölçümüdür. Bacak volümü, optoelektronik yöntemler, yüksek rezolüsyonlu magnetik rezonans görüntüleme gibi geçerliliği henüz tam kabul olmamış yöntemler ile veya dinamik bacak volüm cihazı ve pletismografi gibi daha geçerli metodlarla ölçülebilir. Fakat bu yöntemler hem pahalı hem de rutin olarak kullanımı zordur. Berard ve arkadaşları yaptıkları çalışmada bacak çapı ölçmenin güvenir bir yöntem olduğunu göstermiştir [13]. Bizde bu nedenle bacak ödemini, bacak çevrelerini, preoperatif evrede, postoperatif 1 . hafta ve 1. aylarda, insizyonun 15. cm'den ölçerek değerlendirdik.

\section{Sonuç}

Her iki bacaktan diz eklemini geçmeyen insizyon ile safen ven greft hazırlanan olgularla, safen venin tek bacaktan ve diz eklemini geçen insizyon ile çıkarılan olgular arasında sellülit ve bacak ödemi yönünden istatistiksel anlamlı bir fark olmasa da; bacak ağrısı şikayeti istatistiksel anlamlı derecede daha azdır.

\section{Maddi Destek ve Çıkar îlişkisi}

Çalışmayı maddi olarak destekleyen kişi/kuruluş yoktur ve yazarların herhangi bir çıkar dayalı ilişkisi yoktur.

\section{Kaynaklar}

1. Chukwuemekai A, Lindsay J. Modified incision for long saphenous vein Harvest. Ann Thorac Surg 1998; 66: 279.

2. Kan CD, Luo CY, Yang YJ. Endoscopic saphenous vein harvest decreases leg wound complication in coronary artery bypass grafting patients. J Card Surg 1999; 14: 157-62.

3. Tevaearai HT, Mueller XM, Von Segesser LK. Minimally invasive harvest of the saphenous vein for coronary artery bypass grafting. Ann Thorac Surg 1997; 63: 119-21.

4. Lehmann A, Lang J, Weisse U, Boldt J. Pneumoperitoneum secondary to endoscopic harvest of saphenous vein graft. Ann Thorac Surg 2000; 69: 1937-38.

5. Tianjie Lai, Yarrow Babb, Qian Ning et al. The Transition from Open to Endoscopic Saphenous Vein Harvesting and Its Clinical Impact. Tex Heart Inst J 2006; 33: 316-320.

6. Mueller XM, Tinguely F, Tevaearai HT, Revelly JP, Chiolero R, von Segesser LK. Pain location, distribution and intensity after cardiac surgery. Chest. 2000; 118: 391-96.

7. L'Ecuyer PB, Murphy D, Little JR, Fraser VJ. The epidemiology of chest and leg wound infections following cardiothoracic surgery. Clin Infect Dis 1996; 22: 424-29.

8. Utley JR, Thomason ME, Wallace DJ et al. Preoperative correlated of impaired wound healing after saphenous vein excision. J Thorac Cardiovasc Surg 1989; 98: 147-49.

9. Allen KB, Shaar CJ. Endoscobic saphenous vein harvesting. Ann Thorac Surg 1997; 64: 265-66.

10. Allen $K B$, Griffith $G L$, Heimansohn DA et al. Endoscopic versus traditional saphenous vein harvesting: $A$ prospective, randomized trial. Ann Thorac Surg 1998; 66: 26-32.

11. Ariturk C, Okten M, Gullu U et al. Endoskopik Safen Ven Hazırlanması: Türkiye'deki İlk Deneyimler. Acıbadem Üniversitesi Sağlık Bilimleri Dergisi 2014; 5: 4

12. Terada Y, Fukuda S, Tohda E, Kigawa I, Wanibuchi Y, Mitsui T. Venous function and delayed leg swelling following saphenectomy in coronary artery bypass grafting. Jpn J Thorac Cardiovasc Surg 1999; 47: 559-62.

13. Pagni S, Ulfe EA, Montgomery WD et al. Clinical experience with the video-assisted saphenectomy procedure for coronary bypass operations. Ann Thorac Surg 1998; 66: 1626-31.

14. Berard A, Kurz X, Zuccarelli F, Abenhaim L. Validity of the Leg- O-Meter, an instrument to measure leg circumference. Angiology 2002; 53: 21-28. 